\title{
PECS (Picture Exchange Communication System) terhadap Interaksi Sosial anak ADHD (Attention Deficit-Hyperactive Disorder)
}

\author{
Virgian Ferda Sari ${ }^{1}{ }^{*}$, Ni Wayan Sukerti ${ }^{2}$ \\ ${ }^{1,2}$ Program Studi Pendidikan Luar Biasa, Pascasarjana, Universitas Negeri Surabaya, \\ Jl. Lidah Wetan, Surabaya (60213) \\ *Corresponding Author. E-mail: virgianferda2@gmail.com
}

\begin{abstract}
Abstrak: PECS adalah alternatif sistem komunikasi yang digunakan untuk mengajarkan komunikasi secara fungsional kepada anak. Metode PECS membantu anak mengungkapkan interaksi secara komunikatif. Tujuan dari penelitian ini adalah untuk mengidentifikasi pengaruh PECS terhadap interaksi sosial bermain anak dengan teman sebaya di kelas. Penelitian menggunakan desain Single Subject Reseach (desain subjek tunggal) dengan desain A-B-A. Pengumpulan data menggunakan fase observasi. Penyajian data dengan grafik dan dianalisis dengan analisis visual. Subjek merupakan anak ADHD di sekolah dasar Inklusi kelas 1. Hasil penelitian menunjukan pemberian intervensi (metode PECS) terhadap perubahan target perilaku (interaksi sosial perilaku bermain anak ADHD), menunjukan adanya penurunan penolakan bermain bersama antara anak ADHD dengan teman sebaya dikelas inklusi dengan menggunakan media PECS sebagai intervensi. Pemberian media PECS membuat anak memahami berbagai cara berinteraksi dengan teman sebaya, menimbulkan keinginan anak untuk bermain dengan teman secara non verbal melalui tindakan langsung.
\end{abstract}

Kata kunci: Picture Exchange Communication System, anak ADHD, Interaksi sosial

\section{PECS (Picture Exchange Communication System) on social interaction of Student with ADHD (Attention Deficit-Hyperactive Disorder)}

\begin{abstract}
PECS is an alternative communication system used to teach the child the communication functionally. The PECS method helps the child reveal communicative interactions. The purpose of the study was to identify the influence of PECS on the social iteraction of children playing with peers in the classroom. The study used the design of Single Subject Reseach (single subject design) with A-B-A design. Data collection using the observation phase. Presentation of data with graphs and analyzed by visual analysis. The subject is a child of ADHD in elementary class 1st inclusion school. The results showed that the intervention (PECS method) on the target change in behavior (social interaction of Children's Playbehavior ADHD), showed a decrease in the rejection of the joint play between the ADHD child and his fellow-class inclusion by using the PECS media as an intervention. The media administration of PECS made the child understand the different ways of interacting with peers, raising the child's desire to play with friend non-verbal through direct action
\end{abstract}

Keywords: Picture Exchange Communication System, Student with ADHD, social interaction

\section{PENDAHULUAN}

Masalah yang sering ditemukan pada anak dalam kehidupan sehari-hari baik anak usia prasekolah, sekolah, remaja dan juga dewasa sering mengalami gangguan Pemusatan perhatian dan Hiperaktifvitas (GPPH) atau istilah kedokteran dikenal dengan singkatan ADHD (Attention Deficit Hyperactivity Disorder). Menurut Kauffman, Hallahan, \& Pullen (2017), menjabarkan Anak ADHD (Attention Deficit Hiperactivity Disrder) merupakan salah satu katagori anak berkebutuhan khusus yang mengalami gangguan pada perkembangan otak yang menyebabkan hiperaktif, implusif, serta mengalami kesulitan untuk memusatkan perhatian (inatensi). Tiga gejala utama ADHD yang umum pada anak-anak, yaitu Inattention, Impulsivity, dan Hyperactive.

Anak dengan ADHD menunjukan beberapa gejala utama seperti aktivitas yang berlebihan, tidak bisa diam, senantiasa bergerak, tidak dapat memusatkan perhatian, dan implusif. Gangguan ini merupakan gangguan biologis pada otak yang berlangsung secara kronis sehingga mengakibatkan terganggunya fungsi kognitif. Novriana, Yanis, \& Masri (2014), menjabarakan akibat terganggunya 
fungsi kognitif anak dengan ADHD diantaranya adalah menurunya derajat intelegnsi anak, menurunya prestasi belajar, pengamatan waktu yang kurang baik, penurunan daya ingat baik verbal maupun non verbal. Gangguan ini juga dapat menimbulkan masalah dalam perkembangan kemampuan berbahasa.

Pujiati \& Yulianti (2018), menjelaskan gangguan berbahasa sering dialami oleh anak ADHD, gangguan bahasa yang dialami anak lebih cenderung kepermasalahan fonologi dan pragmatic. Gangguan ini menyebabkan anak kesulitan untuk berkomunikasi dan memahami ujaran dengan baik sehingga sering terjadi kesalahan pengucapan saat berbicara. Terhambatnya kemampuan berbahasa yang dimiliki anak dengan ADHD membuat kemampuan pemrosesan informasi saat melakukan interaksi sosial dengan lingkungannya menjadi kurang. Rendahnya kemampuan interaksi sosial yang dimiliki membuat anak harus memperhatikan perbuatan yang dilakukan orang disekitanya, agar anak dapat menemukan petunjuk-petunjuk sosial disekitarnya, baik petunjuk verbal, nonverbal, Novita (2010).

Gejala defisif perilaku atau impulsivity yang dialami ADHD membuat rendahnya perhatian anak dengan orang disekitarnya, kesulitan memahami informasi sosial, kesulitan dalam tahap pemrosesan informasi dan interaksi sosial. Kesulitan memahami informasi yang diberikan orang disekitarnya menyebabkan kemampuan interaksi anak menjadi rendah, respon yang diberikan tidak sesuai, anak cenderung memberikan respon menolak, menghindar dan menunjukan sikap tidak peduli dengan sekitanya. Novita (2010), menjelaskan anak ADHD mengalami keterlambatan dalam perkembangan sosial dimana ketidakmampuan anak dalam menangkap isyarat-isyarat sosial dan pesan-pesan nonverbal yang ada pada konteks-konteks sosial. Anak ADHD cenderung memiliki sedikit pilihan respon untuk menghadapi situasi sosial dan lebih memilih respon agresif untuk menghadapi situasi sosial. Rendahnya interaksi sosial yang dimiliki anak ADHD biasanya mundul pada pertengahan masa kanak-kanak.

Keterlambatan pada interaksi sosial yang dimiliki anak ADHD membuat anak jarang berkomunikasi dan berinteraksi dengan teman sebayanya. Metode yang digunakan untuk membantu anak dalam menjalin interaksi dan komunikasi dengan teman sebaya salah satunya adalah metode komunikasi PECS (Picture Exchange Communication). Bondy \& Frost (2001), menjabarkan PECS adalah alternative system komunikasi yang dikembangkan untuk mengajarkan komunikasi secara fungsioanl kepada anak. Penggunaan PECS, mengajarkan anak untuk bertukar satu gambar untuk item yang diinginkan dan membuat kalimat sesuai gambar yang dipilih anak sebagai permintaan mereka. PECS digunakan untuk siswa-siswa prasekolah dengan ADHD dan anak disabilitas lainnya yang berkaitan dengan gangguan komunikasi. Siswa yang menggunakan PECS ini adalah mereka yang perkembangan bahasanya kurang dan tidak memiliki kemamuan untuk berinteraksi dan berkomunikasi dengan orang lain.

Howlin, Gordon, Pasco, Wade, \& Charman (2007), menjelaskan PECS dikembangkan untuk anak autis dan anak ADHD, karena kebanyakan anak yang mengalami kesulitan konsentrasi memiliki ingatan visual baik (Visual learnes), yaitu mereka dapat menghafal dengan mudah, dapat memproses banyak materi dengan cepat. Penggunaan metode PECS dilakukan melalui 3 tahap yang disesuaikan dengan tahapan komunikasi anak ADHD yaitu, tahap pertama; cara anak berkomunikasi. Tahap ini guru memegang gambar anak bermain, guru menyampaikan "ini gambar teman-temanmu bermain” anak berusaha mendapatkan gambar sama dengan mengambil gambar di buku komunikasi lalu memberikan kepada guru. Tujuan umum dari fase ini anak dapat mengembangkan fungsi komunikasinya menggunakan PECS. Tujuan khusus yang ingin dicapai adalah anak mengambil sebuah gambar bermain yang mirip.

Tahap kedua, Discrimination, anak mampu mengambil gambar yang dikatakan guru, diberi beragai gambar kegiatan misalnya "lihat teman-temanmu mereka sedang bermain" anak mengambil gambbar bermain di kartu komunikasi dan menyerahkannya ke guru atau ke teman bicara. Tujuan yang ingin dicapai anak meminta item yang sesuai dengan keadaan yang dilihatnya dengan pergi ke buku file komunikasinya. Anak secara mandiri meminta gambar yang sesuai dengan situasi kelas yang dilihatnya, dengan pergi ke buku komunikasinya memilih gambar yang mewakili keadaan yang dilihatnya, pergi ke guru atau ke teman bicaranya dan memberikan gambar.

Tahap ketiga, responsive requsting (menjawab pertanyaan). Maksud dari tahap ini anak dapat menjawab pertanyaan dengan melihat gambar di buku komunikasi ketika guru bertanya "lihat temantemanmu, mereka sedang apa?”. Tujuan yang ingin dicapai anak dapat menjawab dengan melihat teman-temannya sedang bermain, anak memahami bahwa yang dilakukan teman-temannya itu 
namanya "bermain", dengan melihat gambar bermain di buku komunikasinya. Ciptakan kegiatan anak ikut bermain bersama teman-temannya.

\section{METODE}

Penelitian ini menggunakan metode eksperimen, menggunakan pendekatan subjek tunggal atau single subject reseach (SSR). SSR mengacu pada strategi penelitian yang lebih dikembangankan untuk mengamati, dan mendokumentasikan tingkah laku subjek secara individu. Tingkah laku yang dokumentasikan pada penelitian ini adalah tingkah laku penolakan ajakan bermain oleh teman sebaya. Model yang digunakan yaitu model A-B-A desain. Model ini digunakan pada dua kondisi kontrol (baseline) sebelum dan sesudah intervensi. (A1): sesi pengamatan pengamatan perilaku bermain subjek sebelum mendapat intervensi, (B); kegiatan intervensi dengan metode PECS, (A2): penerimaan ajakan bermain setelah intervensi.

\section{Partisipan Eksperimen}

Penelitian ini menggunakan anak ADHD dengan hambatan komunikasi di Sekolah Dasar Inklusi Aeli School. Anak mengalami ADHD dari hasil asesmen psikolog dan asesmen di Pusat layanan Disabilitas Unesa. Pada observasi yang dilakukan subjek merupakan kelas 1 SD di sekolah Inklusi yang dimana subjek belajar dengan teman-teman sebayanya yang normal. Hasil asesmen anak menjabarkan subjek mengalami hambatan berinteraksi dan berkomunikasi dengan teman sekelasnya seperti subjek sering menolak ketika diajak bermain bersama oleh teman-temanya, subjek menjadi marah-marah dengan berguman atau menggigit tangannya. Subjek lebih sering bermain dengan benda sendiri, tanpa mau berbagi dengan temannya. Dalam hal mengantre saat baris berbaris subjek juga rendah, anak sering menerobos antrian, terkadang menjahili temanya dengan menendang kursinya sehingga teman-teman sekelasnya sering menyebut subjek anak nakal. Subjek juga mengalami keterlambatan dalam bicara sehingga kata-kata subjek saat interaksi dengan teman sebayanya sedikit.

\section{Instrumen penelitian}

Penelitian ini terbagi tiga fase, pertama sesi (A1) Pengukuran pada fase observasi (A1) dilakukan dengan mengamati interaksi sosial anak ADHD dalam bermain bersama. Tindakan penolakan bermain bersama dihitung, berapa kali anak menolak diajak bermain bersama. Pengamatan dilakukan selama 5 kali pertemuan dengan waktu penuh di kelas. Kedua, sesi (B) pelaksanaan dengan menggunakan PECS dalam kegiatan bermain bersama saat istirahat di kelas. Ketiga, sesi (A2) mendapatkan hasil intervensi penggunaan PECS dalam kegiatan bermain bersama. Pengamatan dilakukan selama 5 pertemuan. Data dianalisis visual dalam kondisi dan visual antar kondisi

\section{HASIL DAN PEMBAHASAN}

Data hasil penelitian menunjukan perilaku penolakan ajakan bermain mengalami penurunan setelah diberikan intervensi. Pasa sesi baseline (A1) frekuensi penolakan ajakan bermain anak tertinggi pada sesi ke-1, ke-2, dan ke-3 yaitu sebanyak 4 kali penolakan. Sedangkan frekuensi terendah pada sesi ke-4 dan ke-5 yaitu sebanyak 3 kali penolakan ajakan bermain. Pada sesi intervensi penolakan ajakan bermain subjek berada pada frekuensi terendah yaitu pada sesi ke-6 sampai ke-15. Penggunaan metode PECS saat intervensi menarik perhatian subjek untuk bermain dengan teman sebayanya. Pada sesi Baseline (A2) penolakan ajakan bermain subjek berada pada fase terendah yaitu pada sesi ke-18, ke-19 dan ke-20 dengan frekuensi 2, dan tertinggi pasa sesi ke-16 dan ke-17 dengan 3 frekuensi. Penggambaran secara visual melalui gambar 1. 
J PK (J urnal Pendidikan Khusus), 16 (1), 2020 - 31

Virgian Ferda Sari, Ni Wayan Sukerti

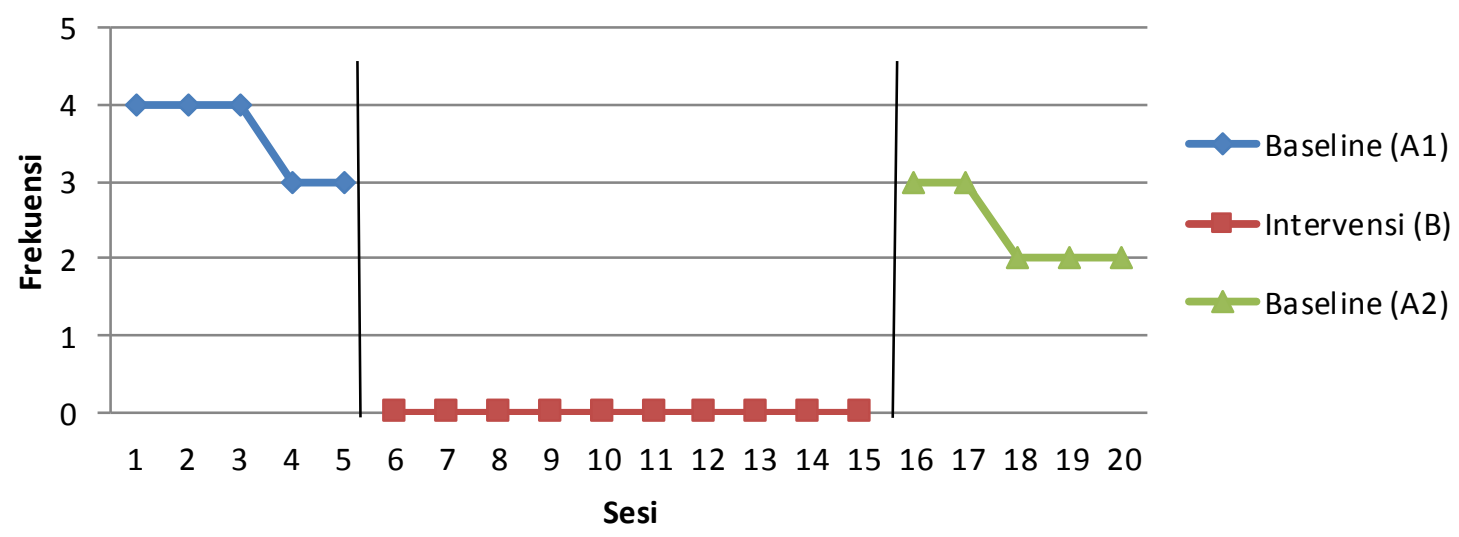

Gambar 1.

Perilaku penolakan ajakan bermain fase A1-B-A

Analisis visual dalam kondisi pada sesi baseline 1 (A-1) mengalami perubahan jejak data menurun, mendatar, menurun secara stabil sehingga menimbulkan kecenderungan arah menurun namun kecil. Pada sesi intervensi (B) anak mengalami hal berbeda dari sesi (A1) anak mengalami perubahan kecenderungan arah yang mendatar yang frekuensi $0 \%$ atau tidak ada. Pada sesi baseline 2 (A-2) anak mengalami penurunan frekuensi dalam penolakan ajakan bermain sehingga akhirnya menimbulkan kecenderungan arah yang menurun. Analisis dalam kondisi ditunjukan pada tabel 1.

Tabel 1.

Rekapitulasi hasil Analisis Visual Dalam Kondisi perilaku penolakan bermain bersama anak ADHD.

\begin{tabular}{|c|c|c|c|c|}
\hline No. & Kondisi & $\mathbf{A 1} / \mathbf{1}$ & $\mathrm{B} / \mathbf{1}$ & A2/1 \\
\hline 1. & Panjang kondisi & 5 & 10 & 5 \\
\hline \multirow[t]{2}{*}{2.} & Estimasi kecenderungan arah & & & \\
\hline & & $(-)$ & $(=)$ & $(-)$ \\
\hline \multirow[t]{2}{*}{3.} & Kecenderungan stabilitas & Stabil & Variebel & Stabil \\
\hline & & $100 \%$ & $0 \%$ & $100 \%$ \\
\hline \multirow[t]{2}{*}{4.} & Estiminasi jejak data & & & \\
\hline & & $(-)$ & $(=)$ & $(-)$ \\
\hline 5. & Level stabilitas dan rentang & $\begin{array}{l}\text { Stabil } \\
(3-4)\end{array}$ & $\begin{array}{c}\text { Variabel } \\
(0-0)\end{array}$ & $\begin{array}{l}\text { Stabil } \\
(2-3)\end{array}$ \\
\hline \multirow[t]{2}{*}{6.} & Level perubahan & $(4-3)$ & $(0-0)$ & $(3-2)$ \\
\hline & & +1 & $=0$ & +1 \\
\hline
\end{tabular}

Analisis antar kondisi dari sesi baseline (A-1) ke sesi intervensi (B) tidak mengalami data yang tumpang tindih (overlap), begitu pula pada sesi intervensi (B), sesi baseline 2 (A-2) tidak mengalami data yang tumpang tindih dengan hasil presentase 20\%. Analisis antar kondisi ditunjukan pada tabel 2. 


\section{J PK (J urnal Pendidikan Khusus), 16 (1), 2020 - 32}

Virgian Ferda Sari, Ni Wayan Sukerti

Tabel 2.

Rekapitulasi hasil Analisis Visual antar Kondisi perilaku penolakan bermain bersama anak ADHD.

\begin{tabular}{|c|c|c|c|}
\hline No. & Perbandingan Kondisi & B1/A1 & B1/A2 \\
\hline 1. & Jumlah variabel yang diubah & 1 & 1 \\
\hline \multirow[t]{2}{*}{2.} & $\begin{array}{l}\text { Perubahan kecenderungan arah } \\
\text { dan efeknya }\end{array}$ & & \\
\hline & & $(=)$ & $(=)$ \\
\hline 3. & Perubahan kecenderungan & $\begin{array}{l}\text { Stabil ke } \\
\text { Variabel }\end{array}$ & $\begin{array}{l}\text { Variabel ke } \\
\text { Stabil }\end{array}$ \\
\hline 4. & Perubahan level & $3-0=3$ & $3-1=2$ \\
\hline 5. & Persentase overlap & $\frac{4}{5} \times 100 \%=20 \%$ & $\frac{4}{5} \times 100 \%=20 \%$ \\
\hline
\end{tabular}

Berdasarkan hasil analisis data menunjukan frekuensi anak dalam penolakan ajakan bermain berada pada kisaran 2 kali penolakan pada sesi intervensi setelah diberi beberapa kali perlakuan dengan metode PECS mengalami penurunan frekuensi penolakan ajakan bermain anak ADHD. Kecenderungan menurunnya perilaku penolakan ajakan bermain anak ADHD dampak dari penggunaan PECS diduga terus meningkat seiring dengan perkembangan komunikasi anak dalam kehidupan sehari-hari. Menurunya frekuensi anak dalam penolakan ajakan bermain beriringan dengan bertambahnya konten yang dikomunikasikan oleh anak. Sehingga material yang digunakan dalam PECS semakin bertambah.

Terhambatnya perkembangan bahasa membuat anak dengan ADHD mengalami keterlambatan dalam interaksi sosialnya, dengan demikian anak dengan ADHD diajarkan berkomunikasi menggunakan augumentatif/alternative communication, salah satu yang paling umum digunakan adalah sistem komunikasi visual atau berbasis pada gambar (PECS). Koudys (2012), menjabarkan penggunaan PECS secara konsisten dengan terapis ataupun orang tua yang terlatih menggunakan PECS sebagai komunikasi membuat anak mengalami penikatan kemampuan komunikasi secara verbal, nonverbal, dan pengurangan perilaku adaptif yang terjadi pada anak dengan hambatan komunikasi.

Pemberian PECS membuat anak ADHD memahami berbagai cara berinteraksi dengan teman sebayanya. Sehingga menimbulkan keinginan anak untuk memulai menerima ajakan bermain, baik secara verbal dan non verbal berupa tindakan langsung. PECS bersifat visual, sehingga anak dalam proses pemahaman infomasi langsung bisa membuat respon sesuai dengan informasi yang didapat secara visual. Respon yang diberikan berupa tindakan Ini sesuai dengan penelitian yang dilakukan. Anggraini \& Purbaningrum (2016), menjelaskan bahwa media visual memiliki peranan penting dalam proses kognitif anak seperti dalam proses belajar, memperlancar pemahaman, memperkuat ingatan dan membuat minat siswa dalam belajar lebih banyak.

Bermain merupakan salah satu kegiatan anak yang meningkatkan interaksi sosial dengan teman di sekolah. Berkurangnya penolakan perilaku bermain anak dengan ADHD membuat anak menerima keadaan lingkungan sosial yang dihadapi. Erinta \& Budiani (2012), menjabarkan terapi permainan sosialisasi dalam menurunkan perilaku implusif pada anak ADHD, sangat efektif digunakan. Dengan aktifnya anak bermain, dan anak memahami bagaimana permainan itu menimbulkan keinginan yang kuat untuk anak bersosialisasi dalam permaianan yang diciptakan.

Anak ADHD yang mengalami keterlambatan dalam interaksi sosial di kelas kebanyakan ditunjukan dengan senangnya melakukan aktivitas sendiri, seperti bermain sendiri, dan tidak mau berbagi dengan teman sebayanya, seringkali anak ADHD menolak untuk diajak bermain bersama, sehingga membuat teman-temannya kurang berniat mengajak mereka bermain. Ini membuat anak ADHD tertinggal dalam perkembangan sosial mereka Diahwati, Hariyono, \& Hanurawan (2016). Ketidakmampuan anak ADHD menangkap isyarat-isyarat sosial dan pesan-pesan nonverbal yang ada pada konteks-konteks sosial. Anak ADHD cenderung memiliki sedikit pilihan respon untuk 
mengahadapi situasi sosial dan lebih memilih respon agresif untuk mengahadapi situasi sosial, seperti bertindak diluar kendali, sering menolak ketika diajak bermain dan suka marah-marah.

Novita (2010), menjabarkan usaha yang dilakukan untuk membantu anak ADHD mengeksekusi pengetahuan yang dimilikinya menjadi perilaku adalah melibatkan manipulasi lingkungan sebagai sumber umpan balik terhadap respon-respon yang dipilih anak. Lingkungan yang dapat dipilih adalah teman sebaya dan orang dewasa disekitar anak. PECS tepat diberikan kepada anak ADHD karena PECS bersifat visual dan gambar-gambar yang disajikan berupa keadaan lingkungan yang benar-benar nyata, membuat anak mengolah informasi secara langsung dengan tindakan yang dimunculkan sesuai gambar.

Tiga tahapan PECS yaitu tahap cara anak berkomunikasi, tahap discrimination, dan tahap implusive question diberikan pada anak yang mengalami kesulitan berinteraksi dengan lingkungan sekitanya, pada tahapan discrimination anak memahami interaksi dan sosialisasi dalam kegiatan yang dilakukan dengan mengamati dan memahami situasi sosial pada gambar visual PECS. Pada tahapan ini anak memahami cara-cara bermain dengan melihat gambar bermain, membuat anak ingin melakukan seperti yang terlihat digambar. Tahapan ini membuat anak ketika diajak bermain oleh teman sebaya menjadi bersemangat dan merespon ajakan temannya. Sesuai dengan penelitian yang dilakukan oleh, Suryaningsih (2016), menjabarkan bahwa pelatihan interaksi sosial dapat dilakukan untuk meningkatakan komunikasi anak dengan ADHD.

Penggunaan media PECS terhadap anak ADHD usia anak-anak, disamping dapat mengurangi perilaku penolakan ajakan bermain juga dapat mengoptimalkan interaksi sosial aspek lainnya. Media PECS bersifat visual dapat digunakan sebagai media untuk mengoptimalkan aspek komunikasi dan kognitif anak. Romadona, Listiana, \& Kurniati (2016), menyatakan Ketrampilan sosial anak ADHD dalam aspek asertif, tanggungjawab, empati, dan kontrol diri dapat meningkat dengan diterapkan bimbingan perilaku dengan teknik token reinforcement dan respon cost yang diterapkan dengan pemberian gambar-gambar yang disukai anak untuk membuat anak berperilaku positif.

\section{SIMPULAN}

Analisis data visual dalam kondisi pada sesi baseline 1 (A-1) mengalami perubahan jejak data menurun, mendatar, menurun secara stabil sehingga menimbulkan kecenderungan arah menurun namun kecil. Pada sesi intervensi (B) anak mengalami hal berbeda dari sesi (A1) anak mengalami perubahan kecenderungan arah yang mendatar yang frekuensi $0 \%$ atau tidak ada. Pada sesi baseline 2 (A-2) anak mengalami penurunan frekuensi dalam penolakan ajakan bermain sehingga akhirnya menibulkan kecenderungan arah yang menurun.

Analisis antar kondisi dari sesi baseline (A-1) ke sesi intervensi (B) tidak mengalami data yang tumpang tindih (overlap), begitu pula pada sesi intervensi (B), sesi baseline 2 (A-2) tidak mengalami data yang tumpang tindih dengan hasil presentase $20 \%$.

Berdasarkan hasil penelitian dapat disimpulkan pemberian intervensi (metode PECS) terhadap perubahan target perilaku (interaksi sosial penolakan ajakan bermain anak ADHD), menunjukan adanya penurunan penolakan bermain bersama antara anak ADHD dengan teman sebayanya dikelas inklusi dengan menggunakan media PECS sebagai intervensi. Pemberian media PECS membuat anak memahami berbagai cara berinteraksi dengan teman sebaya. Sehingga menimbulkan keinginan anak untuk bermain dengan teman, secara non verbal melalui tindakan langsung.

\section{DAFTAR PUSTAKA}

Anggraini, V. D., \& Purbaningrum, E. (2016). JURNAL PENDIDIKAN KHUSUS PENDEKATAN PICTURE EXCHANGE COMMUNICATION SYSTEM ( PECS ) TERHADAP KEMAMPUAN BICARA DAN KOMUNIKASI PROGRAM KEBUTUHAN KHUSUS PADA SISWA AUTIS DI SLB Diajukan kepada Universitas Negeri Surabaya untuk Memenuhi Persyaratan Penyelesaia. Jurnal Pendidikan Khusus, 7(4), 1-7. Retrieved from https://jurnalmahasiswa.unesa.ac.id/index.php/jurnal-pendidikan-khusus/article/view/13802

Bondy, A., \& Frost, L. (2001). The Picture Exchange Communication System (PECS). Behavior Modification. https://doi.org/10.1177/0145445501255004 
Diahwati, R., Hariyono, H., \& Hanurawan, F. (2016). Ketrampilan Sosial Siswa Berkebutuhan Khusus di Sekolah Dasar Inklusi. Jurnal Pendidikan: Teori, Penelitian, Dan Pengembangan. https://doi.org/10.17977/JP.V1I8.6682

Erinta, D., \& Budiani, M. S. (2012). Efektivitas penerapan terapi permainan sosialisasi untuk menurunkan perilaku impulsif pada anak dengan. Jurnal Psikologi.

Howlin, P., Gordon, R. K., Pasco, G., Wade, A., \& Charman, T. (2007). The effectiveness of Picture Exchange Communication System (PECS) training for teachers of children with autism: A pragmatic, group randomised controlled trial. Journal of Child Psychology and Psychiatry and Allied Disciplines. https://doi.org/10.1111/j.1469-7610.2006.01707.x

Kauffman, J. M., Hallahan, D. P., \& Pullen, P. C. (2017). Handbook of Special Education: Second Edition. Handbook of Special Education: Second Edition. https://doi.org/10.4324/9781315517698

Koudys, J. (2012). The Picture Exchange Communication System: A community implementation study. ProQuest Dissertations and Theses.

Novita, S. (2010). Pengaruh Social Stories Terhadap Keterampilan Sosial Anak Dengan AttentionDeficit Hyperactivity Disorder. Jurnal Psikologi Undip, 8(2), 102-116.

Novriana, D. E., Yanis, A., \& Masri, M. (2014). Prevalensi Gangguan Pemusatan Perhatian dan Hiperaktivitas pada Siswa dan Siswi Sekolah Dasar Negeri Kecamatan Padang Timur Kota Padang Tahun 2013. Jurnal Kesehatan Andalas. https://doi.org/10.25077/jka.v3i2.52

Pujiati, T., \& Yulianti, D. M. (2018). GANGGUAN BERBAHASA PADA ANAK DENGAN CIRI ATTENTION DEFICIT HYPERACTIVITY DISORDER (ADHD). Dialektika: Jurnal Bahasa, Sastra, Dan Pendidikan Bahasa Dan Sastra Indonesia. https://doi.org/10.15408/dialektika.v5i1.6005

Romadona, N. F., Listiana, A., \& Kurniati, E. (2016). BIMBINGAN DENGAN TEKNIK PERILAKU (BEHAVIOUR THERAPY ) UNTUK MENINGKATKAN KETERAMPILAN SOSIAL ANAK ADHD (ATTENTION DEFICIT/HYPERACTIVITY DISORDER). Edusentris. https://doi.org/10.17509/edusentris.v3i2.219

Suryaningsih, Y. (2016). PENGARUH LATIHAN KETERAMPILAN SOSIAL TERHADAP PENINGKATAN KEMAMPUAN SOSIALISASI ANAK DENGAN ATTENTION DEFISIT HYPERACTIVITY DISORDER (ADHD) Yeni Suryaningsih*. The Indonesian Journal of Health Science.

\section{PROFIL SINGKAT}

Virgian Ferda Sari adalah mahasiswa Pascasarjana Universitas Negeri Surabaya dengan program studi Pendidikan Luar Biasa. Selain sebagai mahasiswa, Virgian Ferda bekerja sebagai Guru Pendamping Khusus anak berkebutuhan khusus di sekolah Inklusi SD Negeri di Kabupaten Sidoarjo.

Ni Wayan Sukerti selaku author 2 adalah mahasiswa Pascasarjana Universitas negeri Surabaya dengan program studi Pendidikan Luar Biasa. 